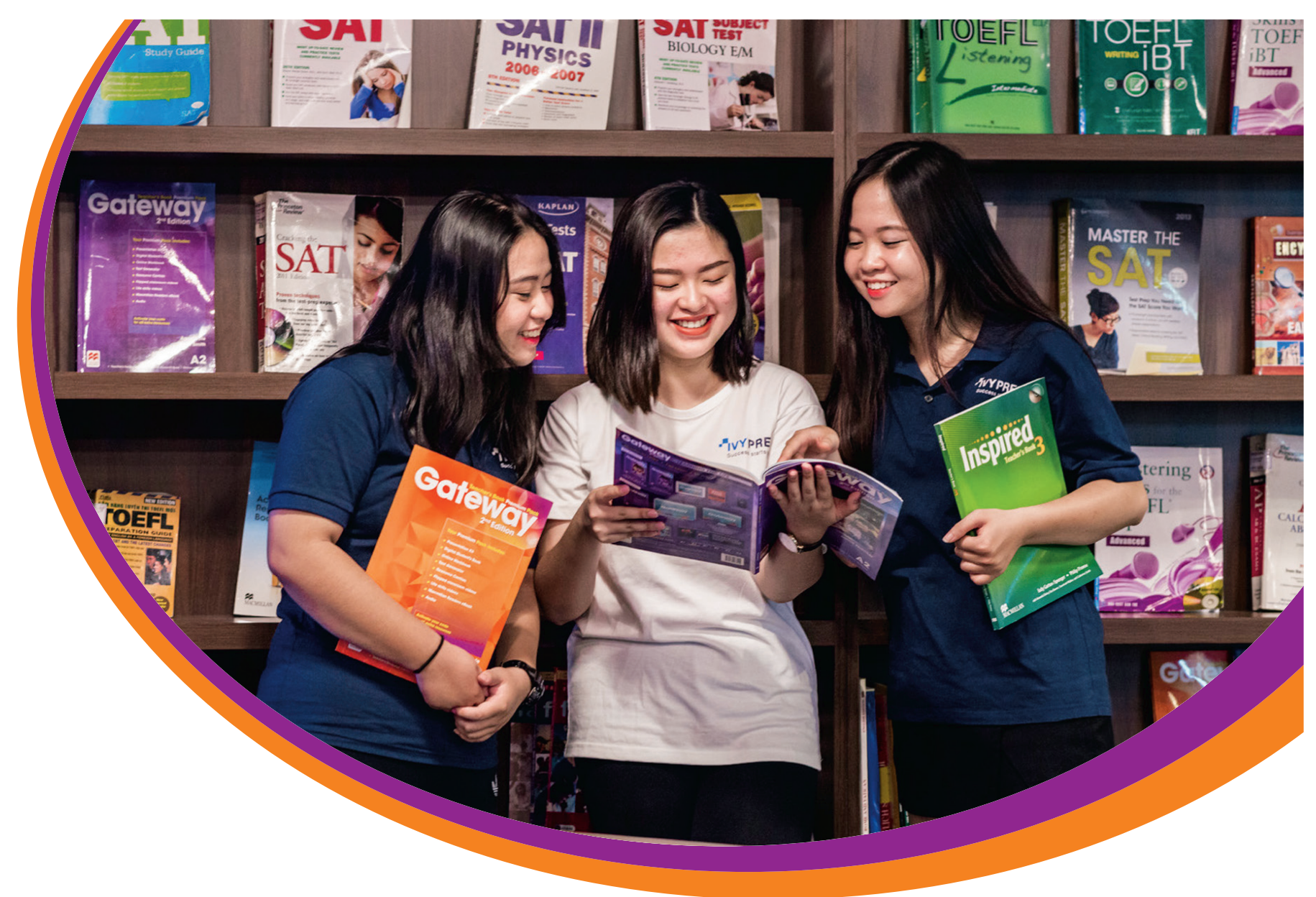

\title{
Chương 2
}

6 tính chất

của Dự án học tập

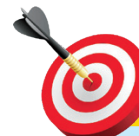

MỤC TIÊU

MT1 - Hiểu được mục tiêu của học tập qua dụ án và sự khác nhau giữa học tập qua dụ án và các dự án thực tế.

MT2 - Hiểu được 6 tính chất cơ bản của học tập qua dụ án. 


\section{VẤN ĐỀ}

\section{KHÁI QUÁT}

Trường học hiện nay đem lại áp lực rất lớn cho học sinh. Khối lượng kiến thức, các hoạt động học tập ngày càng gia tăng, nhưng khả năng thích ứng của học sinh với môi trường sống, với xã hội lại thậm chí có xu hướng suy giảm. Nhiều nền giáo dục trên thế giới đang được vận hành theo hướng nhồi nhét thêm thông tin. Một mặt, chúng ta tin rằng mọi thông tin, kiến thức đều rất cần thiết. Mặt khác, chúng ta lo sợ rằng các em học sinh sẽ bị bỏ rơi trong cuộc ganh đua ngày càng khốc liệt.

\section{CÁCH TIẾP CẬN}

Nếu bạn muốn tham gia một cuộc đua thì hãy nuôi ngựa thay vì nuôi dưỡng những đứa trẻ. Trường học theo mô hình hiện nay bị ảnh hưởng nhiều bởi sự phát triển của thế giới công nghiệp. Nhiều khi, các nhà quản lý tập trung quá mức để trường học cố đạt hiệu quả cao nhất với mức chi phí thấp nhất mà lãng quên những mục tiêu khác. Cứ như vậy, trường học trở thành đáp án hoàn hảo cho nhu cầu tạo ra số lượng lớn nhân công để phục vụ những nhu cầu mới nảy sinh của nền công nghiệp.

Thay vì lún sâu vào cuộc đua không đích đến như vậy, ta hãy trở về với cốt lõi của giáo dục - trẻ em. Trẻ nhỏ được sinh ra với tiềm năng để sáng tạo, tò mò và ham quan sát. Thay vì ép buộc trẻ em theo khuôn khổ, ta cần theo dõi quá trình các em phát triển, đưa ra các hoạt động nhằm kích thích tiềm năng, khơi dậy đam mê và rèn luyện tính sáng tạo của các em.

\section{Mục tiêu của học tập qua dự án và sự khác nhau giữa học tập qua dự án và các dự án thực tế}

Học tập qua dư án và các dự án thực tế khác nhau ở mục tiêu thực hiện. Trong khi người làm dự án thật có mục tiêu cơ bản là hoàn thành dự án, bất kể do công việc, sở thích hay theo yêu cầu, các dụ án học tập lại có chủ đích đạt được các giá trị giáo dục. Mục tiêu của dư án học tập không phải là hoàn thiện sản phẩm cuối cho bằng được hay thương mại hoá sản phẩm, mà thông qua quá trình tìm hiểu vấn đề, phát triển giải pháp, triển khai dự án để học sinh có thể hình thành được các kiến thức, kỹ năng và quan trọng hơn cả là thái độ học tập, nghiên cứu chuyên nghiệp.

Có rất nhiều hình thức khác nhau để triển khai một $d u ̛$ án học tập, tuỳ thuộc vào mục tiêu học tập mà dự án hướng tới. Một dự án có thể diễn ra trên lớp, giải quyết một vấn đề trong một môn học, hoặc ở phạm vi bên ngoài trường học, giải quyết một vấn đề thực tế đời sống. Cho dù phạm vi nội dung, quy mô triển khai của các dự án có khác nhau nhưng vẫn cùng chung một phương thức học tập: Học qua việc làm thực tế.

Chính bởi mục tiêu học qua làm, nên các khái niệm của từng chuyên môn (môn học) cần tránh bị gò bó trong các tiêu chuẩn hoá, tập trung vào sự hợp tác và giao tiếp thay vì truyền đạt thông tin. Qua việc lấy bản thể dự án, thay vì các kiến thức, khái niệm làm đối tượng học tập, học sinh được đặt vào vị trí trung tâm để phát huy tính khám phá, đổi mới và sáng tạo. 


\section{6 tính chất cơ bản của học tập qua dự án}

\subsection{Authenticity - tính Xác thụcc}

Trong mỗi môn học hay tổ hợp môn học, các dự án được thiết kế với những vấn đề thực tế mà học sinh quan tâm. Sự giao thoa giữa mối quan tâm của chính học sinh với các kiến thức, kỹ năng sẽ đem lại cho học sinh quá trình trải nghiệm dự án đích thực với niềm đam mê cao. Nói cách khác, khoảng cách giữa kiến thức, kỹ năng mà dự án bao hàm đối với học sinh càng trở nên ngắn lại khi tính xác thực của dự án càng cao.

Một dự án được cho là có tính xác thực cao khi:

- Giải quyết vấn đề, câu hỏi có ý nghĩa với học sinh.

- Học sinh được tham gia vào một vấn đề, câu hỏi (trong công việc, cộng đồng...) đang thực sự được quan tâm và giải quyết bởi người lớn.

- Dự án yêu cầu học sinh tạo ra những kết quả, sản phẩm mang giá trị cá nhân/ giá trị xã hội bên ngoài phạm vi lớp học.

Không phải là một điều bắt buộc, nhưng một điểm chung dễ nhận thấy ở các dự án học tập thành công là sự đảm bảo tính ứng dụng của sản phẩm, giải pháp vào thực tiễn cuộc sống. Trong các lớp học truyền thống, phần lớn công việc của học sinh được cách ly khỏi thế giới thực tiễn, gói gọn trong phạm vi lớp học và hiếm có ai nhìn thấy ngoại trừ giáo viên. Ngược lại, các dự án học tập tạo ra những giải pháp, nhu cầu, lợi ích mới ở cộng đồng bên ngoài lớp học (trong khối lớp, nhà trường, địa bàn dân cư, cộng đồng thành phố, thậm chí cả thế giới). Thay vì gói gọn nội dung môn học vào trong từng lớp học, các dự án học tập cho phép gom nội dung lại xung quanh các vấn đề, thách thức có sự liên quan nhất định. Vai trò của giáo viên sẽ thay đổi so với vai trò truyền thống, trong một bối cảnh mới với sự tham gia tích cực hơn của học sinh, khởi đầu từ câu hỏi đơn sơ nhất: "Tại sao chúng ta lại cần biết điều này?".
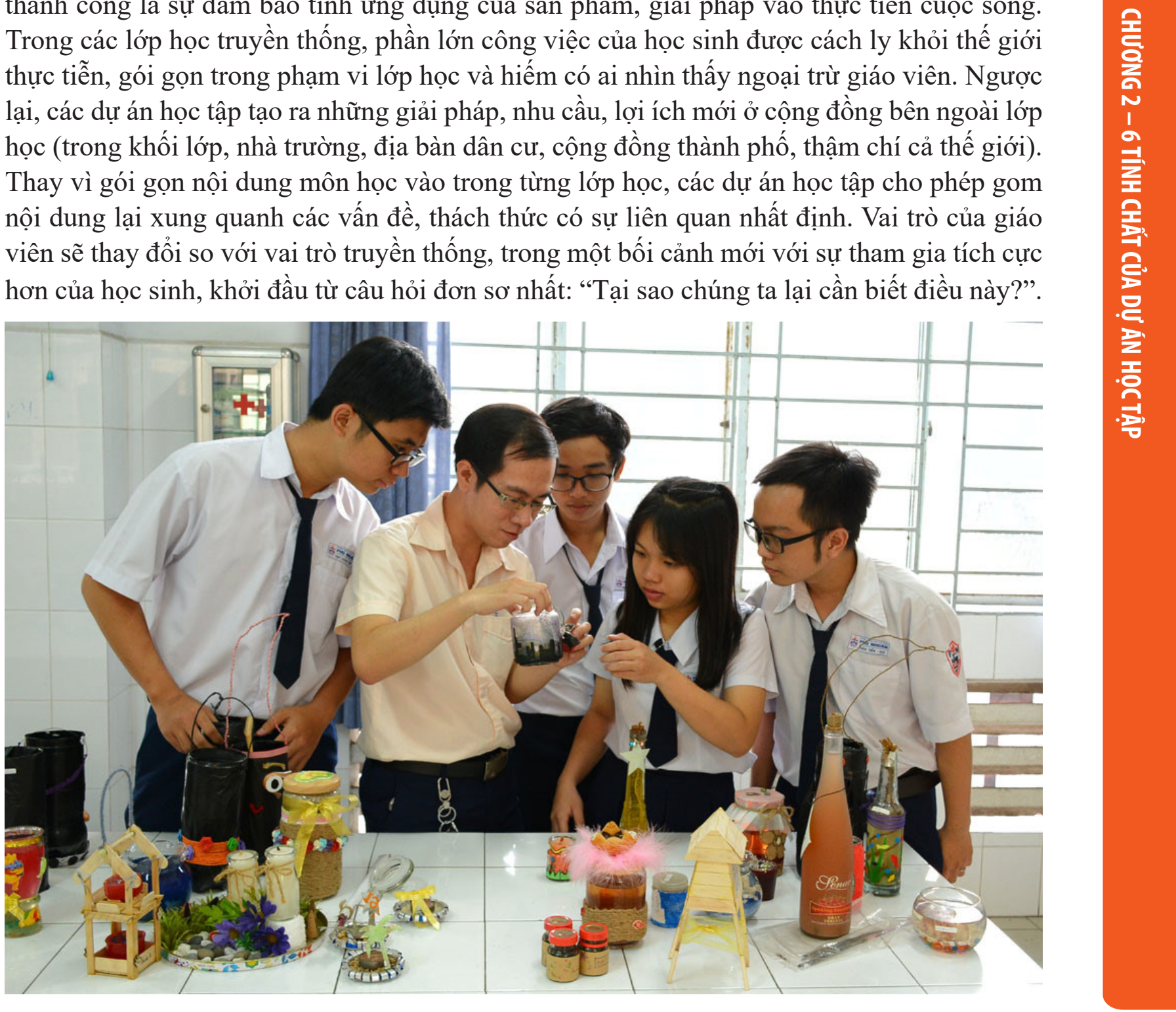

Diễn đàn Giáo dục Sáng tạo Việt Nam - VIEF.edu.vn 


\section{DỰ ÁN “ÚM BA LA, BIẾN NHA... CON MUỖ!!”}

Giáo viên hướng dẫn: Lê Thiên Phúc

Trường THPT Phú Nhuận, TP. Hồ Chí Minh

Bộ môn: Sinh học (lớp 11)

Tích hợp kiến thức môn: Hoá học, Tiếng Anh, Ngữ văn, Tin học, Vật lý

Thời điểm triển khai: Tháng 8/2016

\section{Mục tiêu kiến thức:}

- Hiểu về sự sinh trưởng và phát triển ở động vật;

- Hiểu được vòng đời sinh sản của muỗi;

- Hiểu về cách ngăn chặn, tiêu diệt, phòng trừ các bệnh do muỗi gây ra như sốt xuất huyết, Zika... để bảo vệ sức khoẻ cho bản thân, gia đình và cộng đồng.

\section{Mục tiêu kĩ năng:}

- Lãnh đạo, lập kế hoạch và tổ chức, quản lý thời gian;

- Giao tiếp;

- Hợp tác nhóm;

- Tự đánh giá.

\section{Tính xác thự:}

Tính xác thực của dự án này được thể hiện bởi chính vấn đề mà nó giải quyết, một vấn đề có thực, đang diễn ra và học sinh có thể tham gia giải quyết được. Khoảng thời gian từ tháng 5 đến tháng 11 hằng năm là thời điểm mùa mưa kéo dài, muỗi dễ sinh sôi và gây ra nhiều bệnh nguy hiểm như sốt xuất huyết, sốt rét, Zika... gây ảnh hưởng tới sức khoẻ của học sinh, thầy cô và cộng đồng. Tại thời điểm triển khai dự án, có 7 tỉnh, thành phố tại Việt Nam đã phát hiện người nhiễm virus Zika, đồng thời dịch sốt xuất huyết đang hoành hành ở nhiều nơi, gây ra những diễn biến phức tạp.

Dự án được thực hiện bởi học sinh của 8 lớp 11 và có sự hỗ trợ của học sinh từ 3 lớp 10. Sau quá trình tìm hiểu về kiến thức, học sinh tiến hành triển khai các giải pháp nhằm ứng dụng kiến thức thực tiễn vào đời sống. Các sản phẩm thu được gồm có:

- Sản phẩm về kiến thức: mô hình vòng đời của muỗi, sơ đồ tư duy, cuốn kỷ yếu bằng tiếng Anh.

- Sản phẩm ứng dụng: bình đuổi muỗi, quạt bắt muỗi, các loại nhang, sáp nến, tinh dầu sả.

- Sản phẩm tuyên truyền: tờ rơi, băng rôn, kịch, truyện ngắn, trò chơi trắc nghiệm.

22 Vietnam Innovative Education Forum - VIEF.edu.vn 


\subsection{Academic Rigor - tính Học thuật chính xác}

Tính học thuật chính xác nghe có vẻ xa vời với học sinh phổ thông, nhưng thực ra đó vừa là tiêu chí và phương tiện để rèn luyện tính chuyên nghiệp, sự kiên nhẫn một cách đơn giản nhất. Một dự án có tính học thuật chính xác, nghiêm ngặt sẽ thử thách học sinh bằng các tiêu chuẩn, từ giai đoạn đặt câu hỏi về vấn đề nghiên cứu; tìm kiếm thông tin; thu thập và giải thích dữ liệu; thảo luận logic, sáng tạo để phát triển và đánh giá các giải pháp; phản biện và cải tiến giải pháp cho đến giai đoạn hình thành sản phẩm cuối, thuyết minh và quảng bá kết quả sản phẩm.

Tính học thuật chính xác giúp các em xác định được sự liên kết giữa các mảng nội dung, kiến thức, tập trung tâm trí để hiểu cái cũ và tạo ra cái mới. Hơn thế nữa, quá trình làm quen với việc trích dẫn lại những nghiên cứu, công trình, ý kiến của người khác giúp các em hiểu về đạo đức học thuật, một khái niệm hết sức trừu tượng nhưng dễ nắm bắt và cần thiết cho tương lai, bất kể học sinh sẽ theo con đường nghiên cứu chuyên nghiệp, kinh doanh, hay sinh sống bằng một nghề thủ công...

Tính học thuật chính xác của một dự án có thể được hình thành qua các phương pháp như:

- Hướng dẫn học sinh hiểu rõ sơ đồ liên kết các khái niệm.

- Đề ra một số tiêu chuẩn về việc áp dụng các mảng kiến thức, nội dung vào dự án.

- Thử thách/ gợi ý học sinh sử dụng phương pháp nghiên cứu nhất định (suy nghĩ như một nhà toán học, nhà sử học, hay một nhà soạn nhạc, nhà biên kịch...).

- Yêu cầu học sinh tìm kiếm các quan điểm khác nhau về cùng một vấn đề và bằng chứng cho các quan điểm đó.

Khi giáo viên thiết kế hoặc quan sát học sinh thiết kế dự án, việc đề ra những yêu cầu khắt khe về mặt học thuật đồng nghĩa với việc đưa học sinh vào một cuộc đấu tranh nghiêm túc của các ý tưởng. Học sinh cần phải đưa ra đủ các bằng chứng rõ ràng để bảo vệ ý tưởng của mình, đồng thời cũng chứng minh được việc mình đã làm chủ được các nội dung, kiến thức cần học tập.

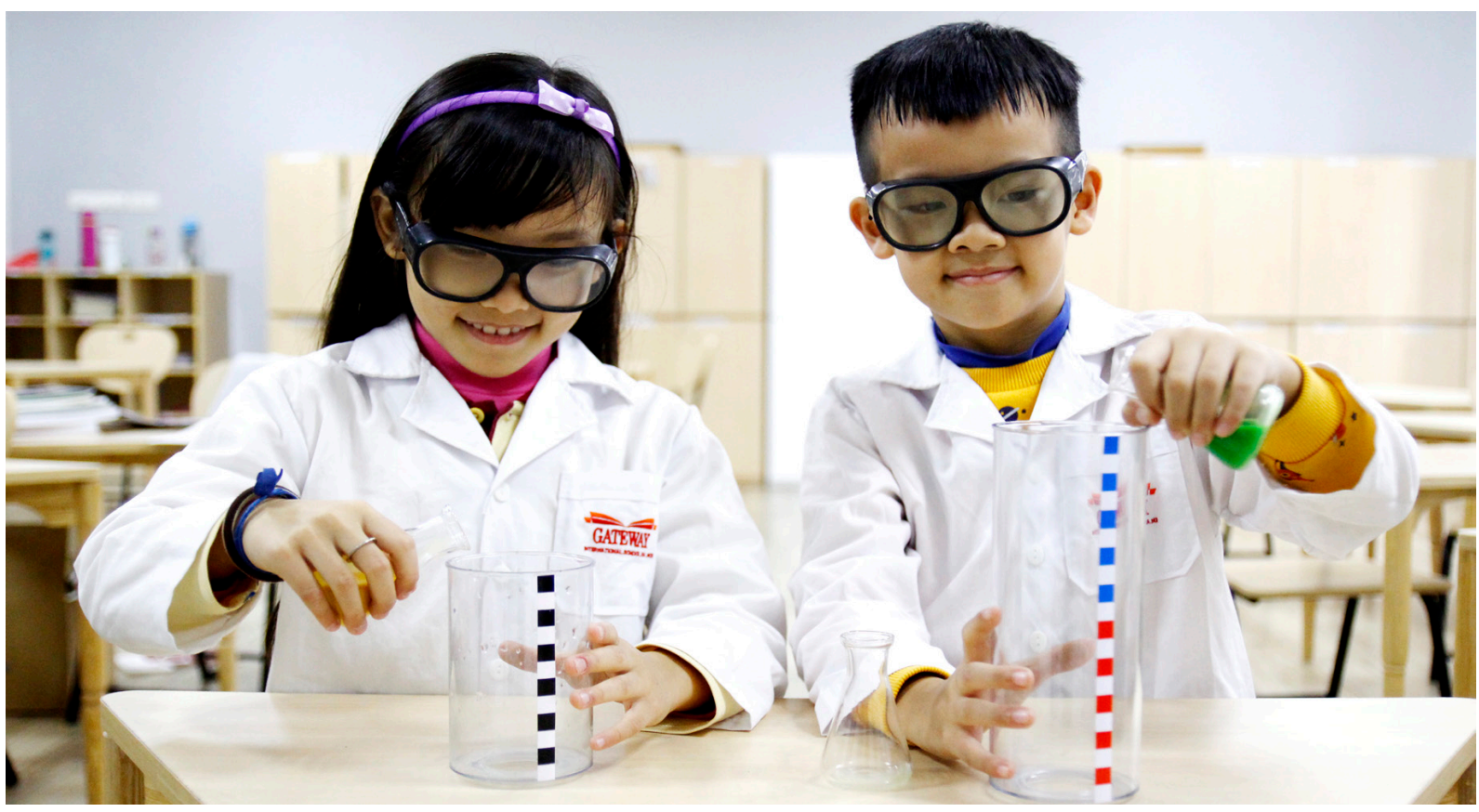

Diễn đàn Giáo dục Sáng tạo Việt Nam - VIEF.edu.vn 


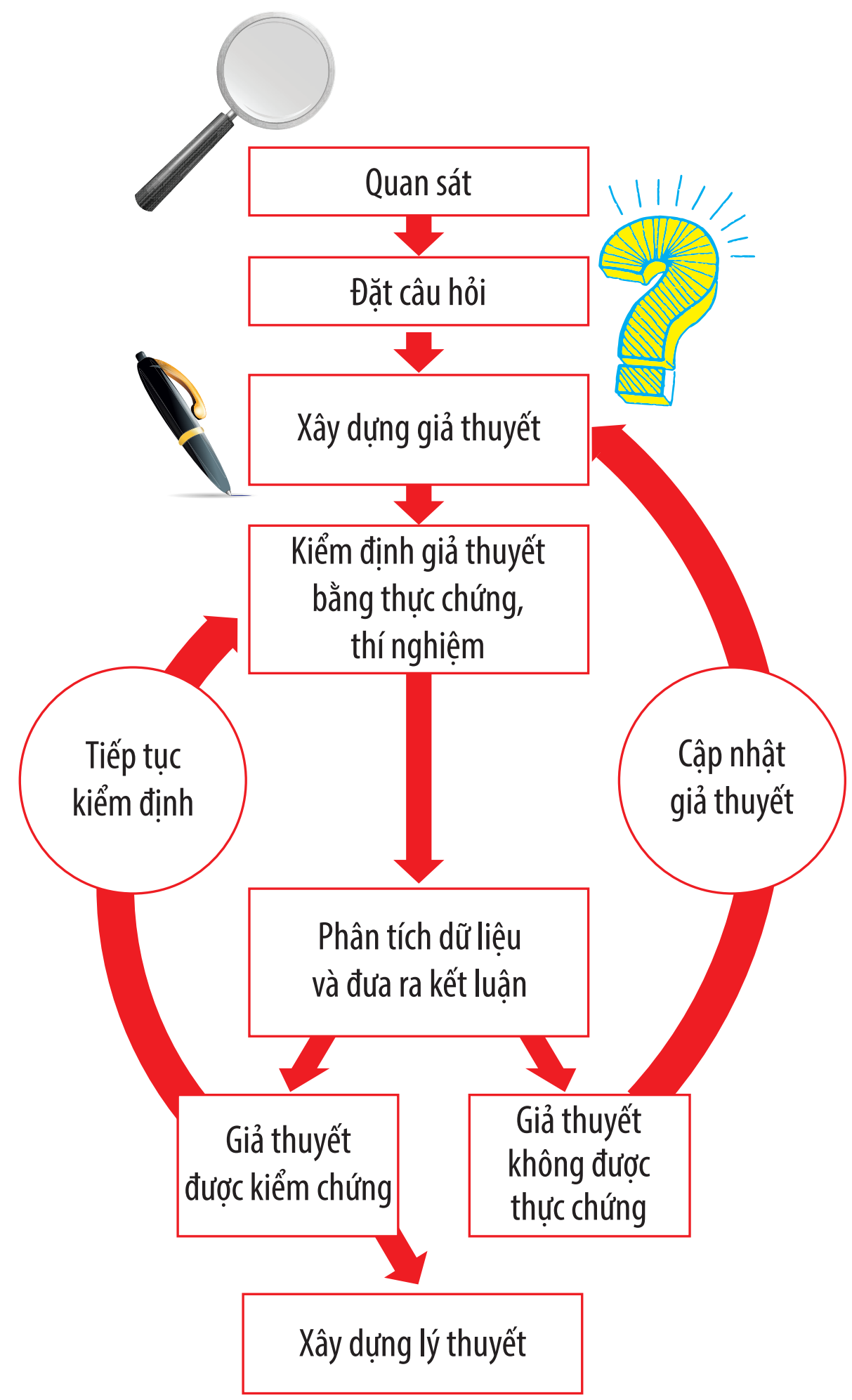

Hình 6. Quy trình nghiên cúvu khoa học

(advanc-ed.org) 


\section{DỰ ÁN “CON ĐÃ LớN”}

Giáo viên hướng dẫn: Trương Hồ Trâm Anh

Trường Tiểu học Lạc Long Quân, TP. Hồ Chí Minh

Tích hợp kiến thức môn: Đạo đức, Kỹ thuật (lớp 5)

Thời điểm triển khai: 2016

\section{Mục tiêu kiến thức:}

- Hiểu thế nào là tự lập.

\section{Mục tiêu kỹ năng:}

- Lãnh đạo, lên kế hoạch và phát triển cá nhân;

- Giao tiếp và làm việc nhóm;

- Tìm kiếm và xử lý thông tin;

- Thuyết trình, tư duy sáng tạo.

\section{Tính học thuật:}

Thoạt nhìn qua, dự án "Con đã lớn” tưởng chừng rất đơn giản, đời thường và không hề liên quan tới "học thuật". Tuy nhiên, dự án đã hoàn thành tốt việc giúp học sinh lớp 5 hình thành được ý thức, tinh thần trách nhiệm cao qua các vòng lặp nghiên cứu - ứng dụng.

Do các yếu tố tâm sinh lý, học sinh ở độ tuổi này còn chưa thực sự tập trung, chủ động tham gia vào các công việc gia đình. Thay vì việc nói, rao giảng cho các em về ý thức, tinh thần trách nhiệm, dự án đặt các em vào vị trí người khai phá - xây dựng những cuốn "Cẩm nang tự phục vụ", hướng dẫn bản thân mình cách làm việc nhà, qua nhiều hình thức khác nhau. Các em cần phải tự tìm hiểu thông tin, tự mình trải nghiệm, đúc rút lại những điểm chính và trình bày lại một cách mạch lạc nhất để người khác hiểu được. Chính yêu cầu tự tìm tòi và kiểm chứng này đã giúp các em có cái nhìn tổng thể về tính tự lập, cũng như phần nào đã thực sự hình thành thói quen tự lập trong từng học sinh.

Các học sinh tham gia dự án đã phát động 2 tuần lễ trải nghiệm "Hãy để con giúp mẹ nhé!" và “Con đã biết tự phục vụ” với nhiều hoạt động ý nghĩa cho từng cá nhân học sinh, cũng như lan toả dự án đến một cộng đồng rộng hơn. Buổi báo cáo kết quả trải nghiệm 2 tuần lễ với chủ đề "Đầu bếp nhí trổ tài" là cơ hội để các em có thể cộng tác và học tập từ kinh nghiệm mà mỗi bạn đã tự thu thập được. Tính chính xác học thuật trong dự án này không phải là một thứ gì đó quá cao siêu, mà rất đơn giản, là tinh thần nghiêm cẩn trong việc tự mình tìm hiểu, tự mình trải nghiệm, không ngừng luyện tập và thu được thành quả từ chính sự nỗ lực của bản thân. Dự án nhỏ bé, đơn giản này tới nay (cuối năm 2018) đã hình thành được một cộng đồng hâm mộ nho nhỏ, với sự góp mặt của hơn 300 nhà giáo dục trong và ngoài nước. 


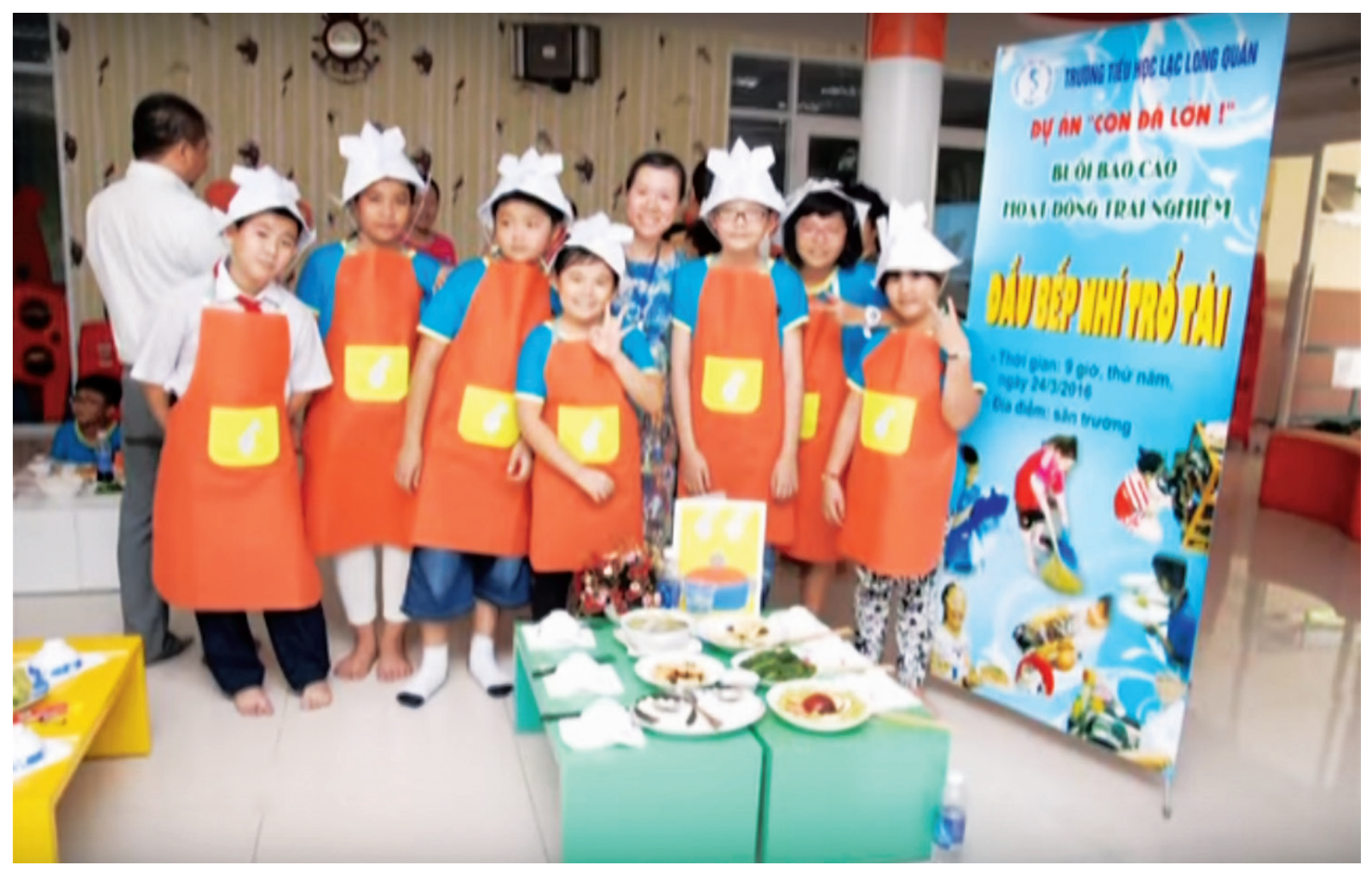

\subsection{Adult Connections - tính Trưởng thành}

Sự kết nối với những đối tượng bên ngoài lớp học là một gợi ý để góp phần cho các dự án vươn ra khỏi phạm vi lớp học. Các kết nối này có thể thực hiện với sự tham gia của những người lớn bên ngoài không gian trường học, vừa gia tăng tính thực tế, vừa gia tăng tính trưởng thành của dự án.

Một số gợi ý để gia tăng các kết nối với người lớn bên ngoài lớp học:

- Học sinh gặp gỡ, quan sát người có kinh nghiệm và chuyên môn liên quan đến dự án.

- Tạo điều kiện để nhóm dự án có thể làm việc chặt chẽ cùng với ít nhất một chuyên gia trong lĩnh vực.

- Đề nghị chuyên gia đóng góp vào việc thiết kế dự án, hoặc đánh giá kết quả dự án.

- Nếu điều kiện địa lý khó khăn, giáo viên có thể kết nối lớp học với chuyên gia qua mạng, thông qua các công cụ như Skype, Google Hangout...

Để đảm bảo cho vai trò hỗ trợ, điều phối của giáo viên không bị sao lãng, sự tham gia của các chuyên gia khác đóng vai trò rất quan trọng trong việc nâng cao tính chuyên nghiệp và sự tập trung của học sinh. Giáo viên hoặc nhà trường có thể mời chuyên gia hỗ trợ trong nhiều hoàn cảnh, giai đoạn khác nhau, không nhất thiết phải song hành trong mọi dự án từ đầu đến cuối. Những chuyên gia này có thể là khách mời nổi tiếng của một buổi trò chuyện, hay sinh viên đại học có chuyên môn nhất định về chuyên ngành của dự án. Quá trình gia tăng các tiếp xúc chuyên môn không chỉ giúp nâng cao chất lượng dự án mà còn giúp học sinh gia tăng tính cam kết học tập, cũng như luyện tập với các kỹ năng giao tiếp liên cá nhân, xây dựng mạng lưới quan hệ cá nhân. 


\section{DỰ ÁN “ƯƠM MẦM MƠ ƯớC”}

Giáo viên hướng dẫn: Trịnh Lan Anh

Trường THPT Thủ Đức, TP. Hồ Chí Minh

Bộ môn: Ngữ văn

Tích hợp kiến thức môn: Địa lý, Giáo dục công dân, Tin học

Thời điểm triển khai: Tháng 9/2016

\section{Mục tiêu kiến thức:}

- Môn Ngữ văn: Giáo dục mục đích, lý tưởng sống; ý nghĩa của ước mo;

- Môn Địa lý: Kiến thức cơ bản về các nhóm ngành nghề (phân loại, sự phát triển, đặc điểm, tính chất), nhu cầu về phát triển nguồn nhân lực;

- Môn Giáo dục công dân: Hiểu và hình thành lý tưởng sống.

\section{Mục tiêu kĩ năng:}

- Phỏng vấn, đặt và trả lời câu hỏi;

- Thuyết minh, thuyết trình;

- Giao tiếp và giải quyết vấn đề;

- Làm việc nhóm;

- Tìm kiếm thông tin, sử dụng các tiện ích miễn phí trên Internet.

\section{Tính trương thành:}

Trong dự án này, học sinh tổ chức từng nhóm để khám phá các nghề nghiệp theo sở thích của mình trong vai nhà điều tra xã hội học, phóng viên. Tính trưởng thành của dự án thể hiện ở quá trình tiếp xúc với những người có chuyên môn thực tế trong từng ngành nghề.

Mỗi nhóm học sinh được kỳ vọng làm ra các sản phẩm:

- Bản khảo sát về xu hướng và nhận thức của học sinh trong việc lựa chọn ngành nghề.

- Video clip giới thiệu về một nghề nghiệp cụ thể, bao gồm đặc điểm, tính chất của nghề, các điều kiện làm việc, quá trình đào tạo, dự báo cơ hội việc làm, chia sẻ của những người trong nghề về các thuận lợi, khó khăn, niềm vui, nỗi buồn...

- Một poster để giới thiệu, quảng cáo cho video clip.

Các kênh truyền thông như trang facebook hay youtube của dự án cũng tiếp tục được duy trì như một kênh thông tin hướng nghiệp cho học sinh của toàn trường. 


\subsection{Active Exploration - tính Khám phá chủ động}

\section{Ce Nghệ thuật giảng dạy là nghệ thuật hỗ trợ cho nhũng khám phá - Mark Van Doren ${ }^{(1)} \partial \partial$}

Các dự án có hoạt động thăm dò thực địa, thực hành thường dễ nhận thấy tính khám phá hơn là các dự án nghiên cứu trên bàn giấy. Sự khám phá của các dự án thuần tuý nghiên cứu tài liệu rất trừu tượng, nên khó hình dung và chuyển hoá được với đối tượng học sinh phổ thông nói chung, nhất là khi các em cần được kích thích sự tò mò nghiêm túc và tính sáng tạo. Những dự án có hoạt động thăm dò, thực hành giúp học sinh vận động tích cực các loại hình tư duy vào việc quan sát, phân tích, ghi chép, đánh giá một cách chủ động.

Một số gợi ý để gia tăng tính khám phá chủ động:

- Yêu cầu nhóm dự án dành phần lớn thời gian cho việc quan sát thực địa.

- Yêu cầu nhóm dự án sử dụng nhiều phương pháp, phương tiện truyền thông khác nhau để trình bày kết quả dự án.

- Tổ chức các cuộc triển lãm chính thức vào cuối học kỳ, cuối năm học để học sinh truyền đạt lại những gì mình học được qua việc trưng bày, thuyết minh sản phẩm.

Việc gia tăng tính khám phá chủ động làm phá đi tư duy đóng băng, hưởng thụ kiến thức thụ động, cho học sinh cơ hội tham gia tìm ra kiến thức bằng con đường của mình, hoặc sử dụng kiến thức theo cách của mình để chứng minh giả thuyết, giải đáp câu hỏi của dự án. Khi học sinh chủ động đặt câu hỏi, khám phá, phân tích và trình bày, các em thực sự học tập sâu hơn và vươn ra ngoài bức tường lớp học bằng chính kinh nghiệm của mình.

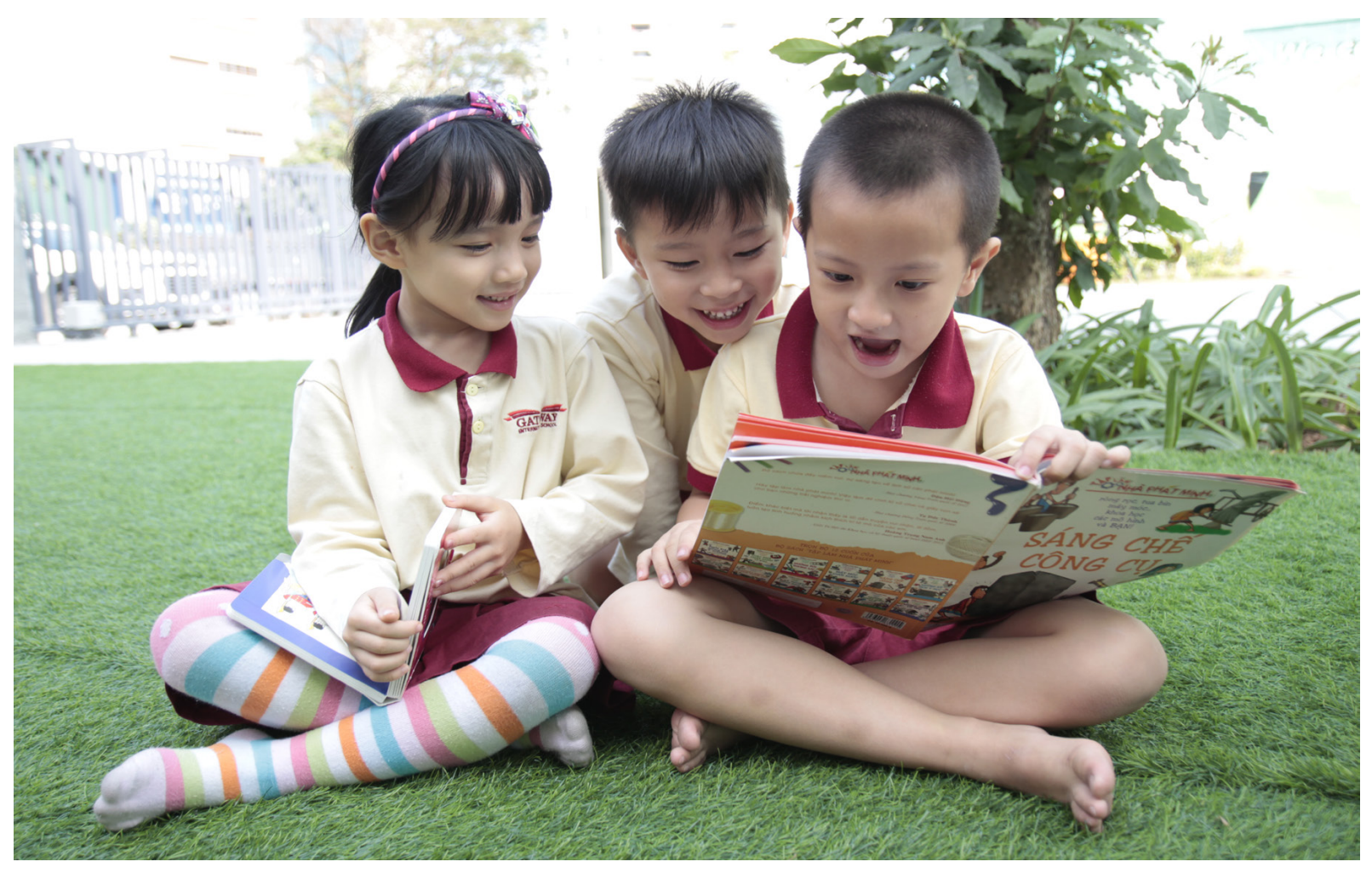

(1) Mark Van Doren (1894-1972), nhà văn, nhà thơ, nhà phê bình văn học người Mỹ, giáo sư ngôn ngữ Anh tại Đại học Columbia.

28 Vietnam Innovative Education Forum - VIEF.edu.vn 


\section{DƯ ÁN “TÔI YÊU TIẾNG NƯớC TÔI”}

Giáo viên hướng dẫn: Trần Thị Quỳnh Anh

Trường THPT Trưng Vương, TP. Hồ Chí Minh

Bộ môn: Ngữ văn (lớp 10)

Tích hợp kiến thức môn: Giáo dục công dân, Tin học

Thời điểm triển khai: 2016

\section{Mục tiêu kiến thức:}

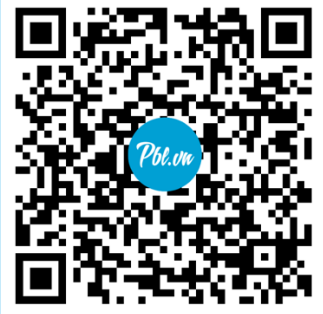

- Nắm được quá trình hình thành, phát triển của tiếng Việt qua các thời kỳ.

- Thấy được vẻ đẹp của tiếng Việt ở các vùng miền khác nhau.

\section{Mục tiêu k̃̃ năng:}

- Rèn luyện kỹ năng tìm kiếm, phân tích, đánh giá và tổng hợp thông tin;

- Rèn luyện kỹ năng làm việc nhóm, sử dụng công cụ tương tác Onenote;

- Thực hành và trải nghiệm các giá trị sống;

- Kỹ năng thực hiện khảo sát bằng Excel Survey.
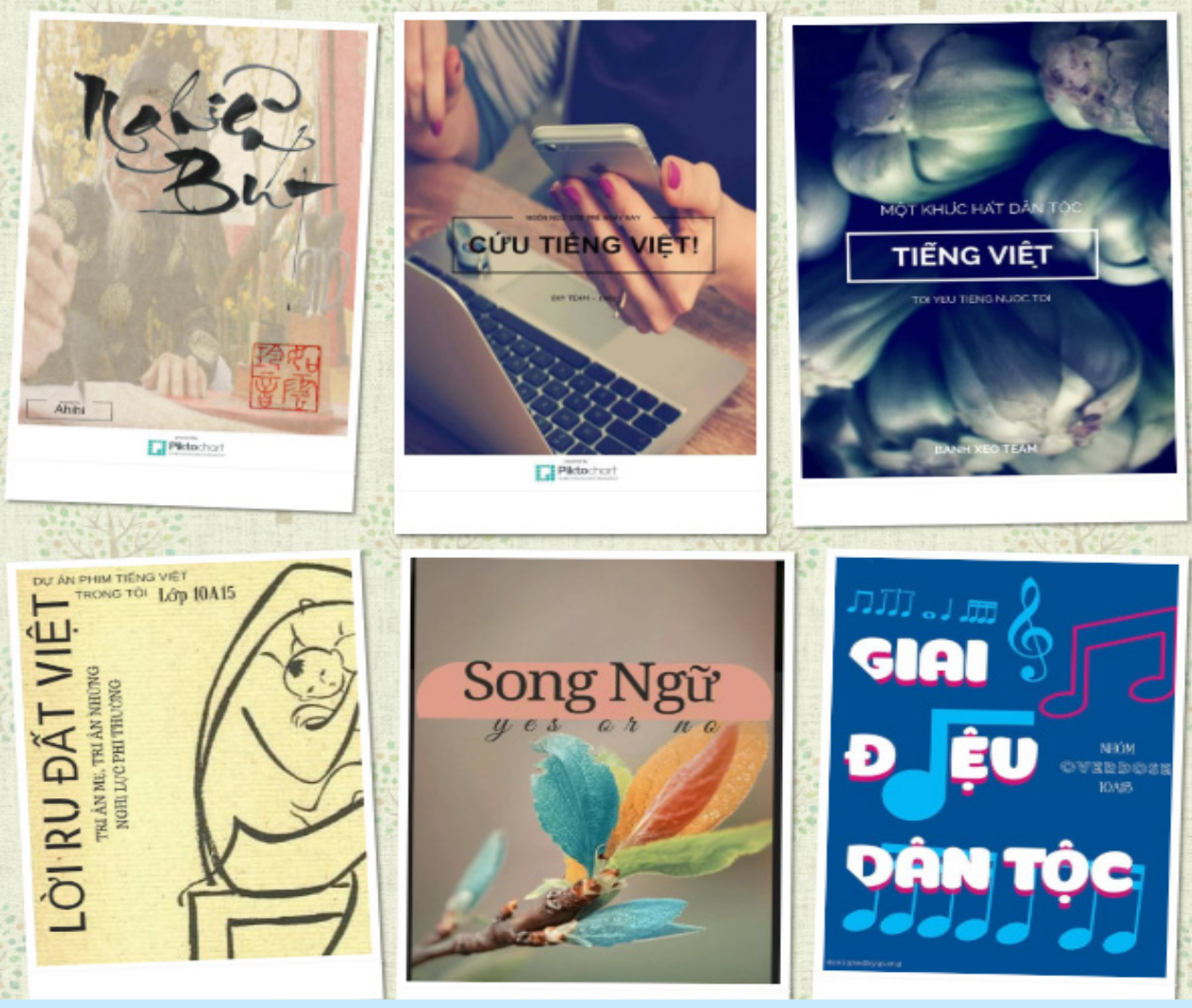

\section{Tính khám phá chủ động:}

Trong dự án này, tính khám phá được thể hiện qua sự trải nghiệm chủ động của từng cá nhân học sinh, sự tương tác, kết hợp giữa các nhóm, cũng như các phương thức đa dạng để trình bày kết quả dự án. 


\section{HỌC TẬP QUA DỰ ÁN}

Dự án bao gồm tám nhóm công việc chính, mỗi nhóm thực chất chính là một dự án nhỏ: (1) Tiếng Việt từ ngàn xưa đến nay; (2) Ngôn ngữ tiếng Việt của giới trẻ hiện nay; (3) Vẻ đẹp của tiếng Việt qua âm nhạc dân tộc; (4) Thư pháp - Kết tinh hồn Việt; (5) Tiếng Việt - ba miền một tiếng nói; (6) Tiếng Việt, hoà nhập hay hoà tan? (7) Lan toả tình yêu tiếng Việt; (8) Khảo sát về việc viết sai chính tả của giới trẻ hiện nay.

Thay vì chờ nhóm khác hoàn tất công việc rồi mình mới bắt đầu, các nhóm học sinh đều chủ động tìm hiểu về công việc của các nhóm khác ngay từ đầu để cùng tương trợ, góp ý lẫn nhau. Bởi vậy, dự án đã có thành quả tổng hoà rất tốt. Các sản phẩm nghiên cứu đều có được hơi thở cuộc sống và các sản phẩm truyền thông cũng dựa trên nền tảng kiến thức cơ bản.

\subsection{Applied Learning - tính Học tập úng dụng}

Tính học tập ứng dụng của dự án có thể hiểu là khả năng học sinh có thể áp dụng ngay các kiến thức mình được học vào thực tế. Cuộc cách mạng công nghiệp lần thứ tư kéo theo sự thay đổi hằng ngày, thậm chí hằng giờ của công nghệ. Chính vì vậy, bên cạnh khả năng nắm bắt và hiểu tốt vấn đề, khả năng ứng dụng tốt đóng vai trò quan trọng cho sự phát triển nghề nghiệp tương lai. Do đó, các dự án học tập cần đề cao việc khuyến khích học sinh ứng dụng và thực hành ngay lập tức các kiến thức, kỹ năng mới.

Giáo viên có thể lưu ý một số phương pháp gợi ý dưới đây:

- Tổ chức bài giảng trong bối cảnh ngoài lớp học, nơi có thể nhìn thấy hoặc thiết lập tình huống thực tế.

- Khuyến khích học sinh thường xuyên đưa ra nhận định về sự kiện, nội dung, phát triển nó thành một vấn đề và tiến hành giải quyết vấn đề theo nhóm.

- Khuyến khích học sinh tự lập kế hoạch theo dõi hiệu năng học tập để các em có thể nhìn nhận lại sau hằng tháng, hằng kỳ.

- Khuyến khích học sinh tự phát triển các kỹ năng tự tổ chức và quản lý các nhóm học tập.

Giáo viên cũng cần lưu ý xây dựng các chuẩn đầu ra (tham khảo Chương 13) trong quá trình thiết kế và giám sát thiết kế dự án. Giúp học sinh ý thức được việc lồng ghép rõ ràng và có chủ đích các tiêu chuẩn về nội dung, kỹ năng tư duy sẽ hình thành thói quen học tập liên tục cho học sinh. 


\section{DỰ ÁN “ALCOHOL HANDMADE”}

Giáo viên hướng dẫn: Huỳnh Công Phúc

Trường THPT Trần Khai Nguyên, TP. Hồ Chí Minh

Bộ môn: Hoá học (lớp 11)

Tích hợp kiến thức môn: Tin học

Thời điểm triển khai: Tháng 3, 4/2016

\section{Mục tiêu kiến thức:}

- Hiểu được tính chất Vật lý, Hoá học và những ứng dụng của alcol;

- Hiểu được những lợi ích tích cực và tác hại của alcol etylic;

- Nắm được các phương pháp chung điều chế alcol, alcol etylic.

\section{Mục tiêu kỹ năng:}

- Kỹ năng thuyết trình;

- Làm việc nhóm;

- Nghiên cứu ứng dụng;

- Tìm kiếm, truy cập, đánh giá và sử dụng thông tin.

\section{Tính học tập ứng dụng:}

Bên cạnh việc tìm hiểu các kiến thức về cồn và rượu, học sinh được chia thành các nhóm để tiến hành sản xuất các loại rượu khác nhau từ chính những nông sản của Việt Nam. Qua đó, học sinh hiểu biết thêm về sự đa dạng, phong phú của nền nông nghiệp nước nhà, cũng như hiểu được tầm quan trọng của việc phát huy thêm những giá trị kinh tế cho các sản phẩm của Việt Nam.

Kết thúc dự án, các nhóm học sinh đã làm được các sản phẩm rượu khác nhau, bao gồm rượu nho, rượu dâu tằm, rượu trái thơm, rượu thanh long ruột đỏ, rượu khế, rượu nếp, rượu cam chuối chanh. Đồng thời, mỗi nhóm cũng có một poster giới thiệu sản phẩm, một clip về quy trình sản xuất, một báo cáo hội nghị về những nội dung liên quan của dự án và một bài thuyết trình.

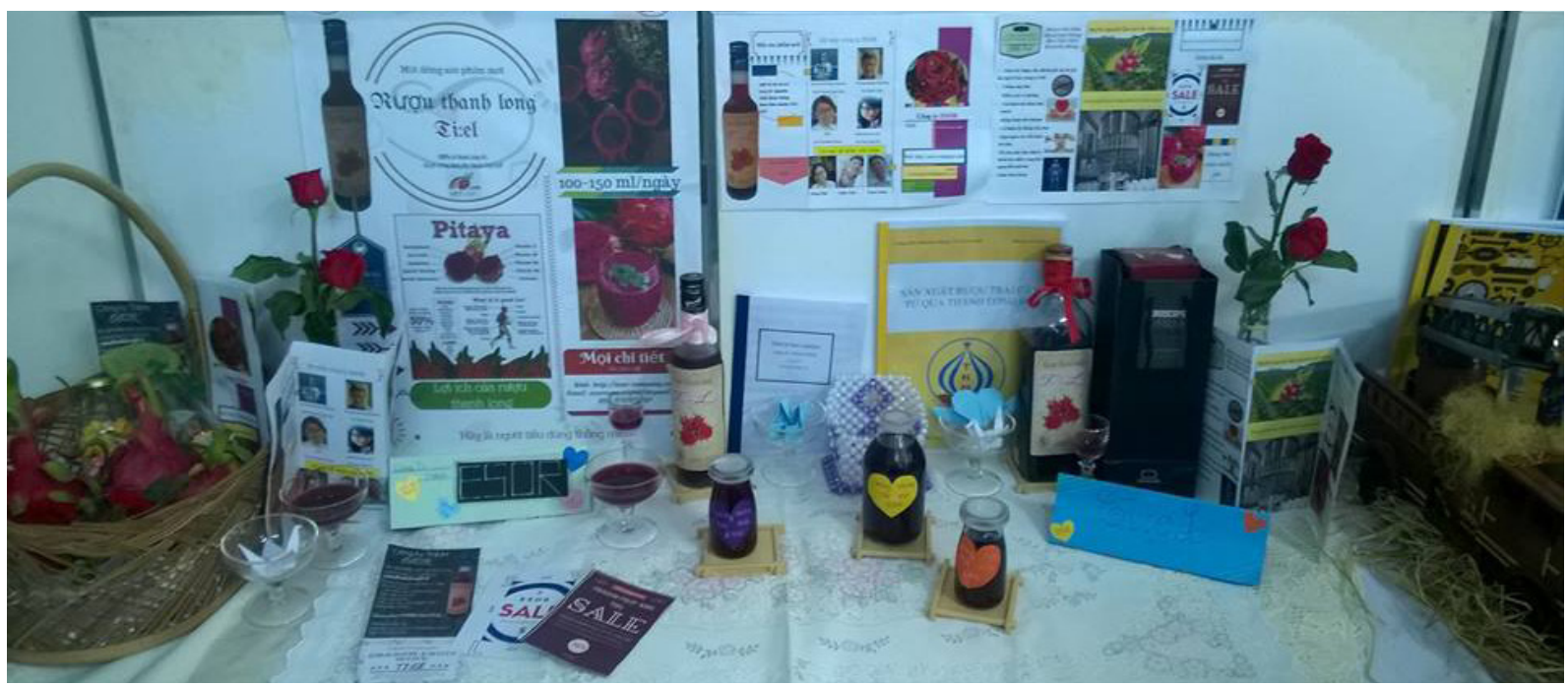




\subsection{Assessment Practices - tính Đánh giá thục tiễn}

Quy trình đánh giá dự án có thể coi là giai đoạn cuối cùng để khép lại một dự án, nhưng cũng có thể tiến hành xuyên suốt dự án. Việc khép lại dự án không có nghĩa là nói lời chào vĩnh biệt với dự án đó. Các hoạt động liên quan để nối tiếp hoặc cải tiến dự án vẫn có thể tiến hành với cùng một nhóm dự án, hoặc các nhóm học sinh bất kỳ muốn nối tiếp/ cải tiến dự án đó. Để đưa ra được quyết định về việc có nối tiếp hay cải thiện một dự án cụ thể, chúng ta cần xem xét đến việc đánh giá thực tiễn của dự án đó. Đồng thời, việc đánh giá dự án cũng giúp cho học sinh nhận được các phản hồi chất lượng ngay cả trong và sau khi các em làm việc.

Một số gợi ý về phương pháp đánh giá thực tiễn dự án:

- Yêu cầu học sinh đưa ra và thường xuyên cập nhật các tiêu chí rõ ràng cho dự án.

- Mời các đại diện bên ngoài lớp học (nhiều đối tượng khác nhau, từ chuyên gia đến công chúng, nhà quản lý, đối tượng thụ hưởng trực tiếp, gián tiếp...) để đánh giá về dự án và giúp học sinh phát triển ý thức về các tiêu chuẩn thực tế.

- Cung cấp cơ hội để học sinh có thể tiến hành đánh giá dự án thường xuyên, như các hoạt động trao đổi chéo giữa các nhóm, xây dựng tạp chí, chuyên san của trường hoặc tiến hành triển lãm dự án.

Quá trình đánh giá dự án phải thu thập và tổng kết được các ý kiến phản hồi để đưa ra kết luận ngắn gọn về tính thực tiễn của dự án. Trong suốt quá trình diễn ra dự án, nhóm dự án có thể tiến hành đánh giá liên tục để nhận phản hồi từ bạn bè, giáo viên, qua đó cải tiến mục tiêu, chất lượng và phương thức tiến hành công việc. Khi kết thúc dự án, nên tiến hành đồng thời cho nhóm dự án tự đánh giá, đánh giá chéo từ các nhóm khác và đánh giá độc lập từ giáo viên và những nhóm công chúng khác.

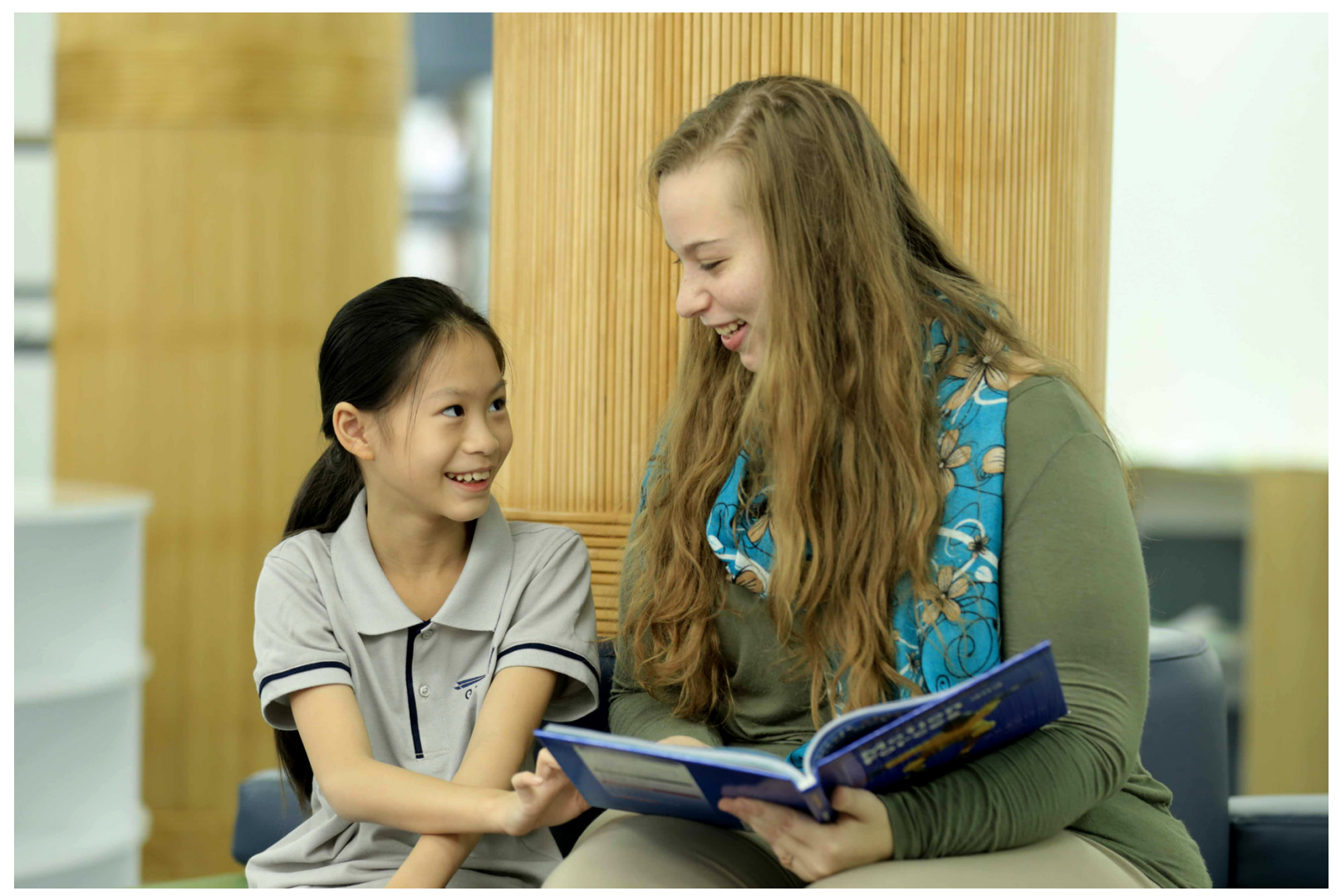

32 Vietnam Innovative Education Forum - VIEF.edu.vn 


\section{DỰ ÁN “I-EAR ĐÔI TAI THÔNG MINH”}

Giáo viên hướng dẫn: Vũ Tấn Hưng, Uông Thị Lệ Giang

Trường THPT Lê Hồng Phong, TP. Hồ Chí Minh

Bộ môn: Sinh học, Vật lý

Tích hợp kiến thức môn: Tin học, Giáo dục công dân

Thời điểm triển khai: Tháng 11/2016

\section{Mục tiêu kiến thức:}

- Hiểu được cấu tạo sinh lý của tai;

- Hiểu nguyên lý truyền dẫn âm thanh;

- Hiểu về các ngưỡng nghe âm thanh, cường độ âm, tiêu âm, ngưỡng âm ảnh hưởng đến sức khoẻ tai;

- Những thói quen ảnh hưởng tới sức khoẻ tai;

- Ô nhiễm âm thanh và sức khoẻ con người;

- Ảnh hưởng của tai nghe đến suy giảm thính lực, phân biệt các loại tai nghe.

\section{Mục tiêu kỹ năng:}

- Tư duy độc lập, tư duy nhóm;

- Giao tiếp và cộng tác;

- Tìm kiếm, truy cập và sử dụng các nguồn thông tin.

\section{Tính đánh giá thục tiễn:}

Đây là một dự án nghiên cứu khoa học liên môn. Dựa trên kiến thức được học, học sinh xây dựng bảng hỏi và tiến hành làm khảo sát, thống kê về các chủ đề: Ô nhiễm tiếng ồn; Thói quen vệ sinh tai; Thói quen sử dụng tai nghe. Bên cạnh những bài báo cáo, tham luận về các chủ đề được nghiên cứu, dự án này còn có các ấn phẩm để tuyên truyền về vấn đề ô nhiễm tiếng ồn và bảo vệ sức khoẻ thính giác. Thêm vào đó, dự án cũng giới thiệu hai sản phẩm để hỗ trợ người câm điếc: Găng tay chuyển ngữ và Phần mềm hỗ trợ tiếp nhận thông tin cho người câm điếc.

Bên cạnh việc đánh giá thường xuyên tiến trình thực hiện để cập nhật các nội dung làm việc, dự án cũng có sự tương tác với các chuyên gia bên ngoài, với những đối tượng thụ hưởng. Ngoài việc các học sinh tự đánh giá và đánh giá chéo, các em còn nhận được những đánh giá sinh động và nhiệt thành nhất từ chính đối tượng thụ hưởng của dự án - những người câm điếc. 


\section{TÓM TẮT CHƯơNG 2}

- Mục tiêu của học tập qua dụ án và sự khác nhau giữa học tập qua dụ án và các dự án thực tế.

- 6 tính chất cơ bản của học tập qua dụ án:

+ Tính Xác thụcc giúp khoanh vùng kiến thức, rút ngắn khoảng cách giữa người học và kiến thức.

+ Tính Học thuật chính xác vừa là tiêu chí, vừa là phương tiện để rèn luyện tính chuyên nghiệp, sự kiên nhẫn.

+ Tính Trưởng thành được thể hiện bởi sự kết nối, mở rộng quá trình học tập với sự tham gia của những chuyên gia bên ngoài lớp học.

+ Tính Khám phá chủ động được hình thành khi học sinh quan sát thực tế, đặt câu hỏi, phân tích và trình bày.

+ Tính Học tập ưng dụng được thể hiện qua khả năng thực hành ngay lập tức các kiến thức, kỹ năng mới vào cuộc sống thực tế.

+ Tính Đánh giá thục tiê̂n đòi hỏi sự tham gia từ nhiều nhóm đối tượng: bạn cùng lớp, cùng trường, giáo viên, phụ huynh, chuyên gia, công chúng...

\section{LIÊN HỆ VÀ THỰC HÀNH}

- Bạn là học sinh? Hãy thử hình dung xem dụ án học tập mà bạn triển khai sẽ ra sao nếu thiếu đi một trong 6 tính chất cơ bản kể trên?

- Bạn là giáo viên? Hãy thử hình dung xem mỗi tính chất cơ bản của học tập qua dụ án có thể giúp bạn phát triển những năng lực gì ở học sinh?

- Hãy nghĩ tới một $\boldsymbol{d u ̣ x ~ a ́ n ~ b a ̂ ́ t ~ k y ̀ ~ v a ̀ ~ đ a ́ n h ~ g i a ́ ~ d u ̛ ̣ ~ a ́ n ~ đ o ́ ~ q u a ~ v i e ̣ ̂ c ~ l i e ̣ ̂ t ~ k e ̂ , ~ p h a ̂ n ~ t i ́ c h ~} 6$ tính chất kể trên.

Các nguồn tài liệu tham khảo:

1. Harada, V. H., Kirio, C., \& Yamamoto, S. (2008). Học tập qua dụ án: Tính thiết thực và phù hơp trong truờng phổ thông. Tạp chí Kết nối Thông tin Thư viện, 26(6), 14.

2. Hmelo-Silver, C. E. (2004). Học tập qua dư án: Học sinh học gì và học thế nào? Tạp chí Tâm lý học Giáo dục, 16(3), 235-266.

3. Jones, B. F., Rasmussen, C. M., \& Moffitt, M. C. (1997). Giải quyết vấn đề thưc tế: Một phương pháp tiếp cận đối với học tập liên môn. Hiệp hội Tâm lý học Hoa Kỳ.

4. Laur, D. (2013). Trải nghiệm học tập đích thục: Cách tiếp cận thực tế với học tập qua dụ án. NXB Routledge.

5. Steinberg, A. (1998). Thực học, thực làm: Cải tổ trưòng phổ thông qua việc đưa nhà trường tới thực tế. NXB Tâm lý học.

34 Vietnam Innovative Education Forum - VIEF.edu.vn 